\title{
Localización ectópica (subdiafragmática) de riñón derecho
}

\author{
Garrido Abad P, Muñoz-Delgado Salmerón J, Herranz Fernández LM.
}

Servicio de Urología. Policlinica Nuestra Señora de América. Madrid

Actas Urol Esp. 2007;31(5):570

$\mathrm{V}$ arón de 83a. que acude a consulta de urología por primera vez con síntomas de tracto urinario bajo (LUTS) de aparición en los últimos años.

En analítica se detecta un PSA: 12,8 e IPSA: 0,14 siendo el tacto rectal normal. Seguidamente se realizan ecografia transrectal y biopsia de próstata, sin hallazgos de interés en la primera (Vol. 29cc), ni sugerentes de malignidad en esta última.

Posteriormente se realiza ecografia abdominal, no visualizándose durante la prueba el riñón derecho. Debido a ello se cree conveniente la rea-

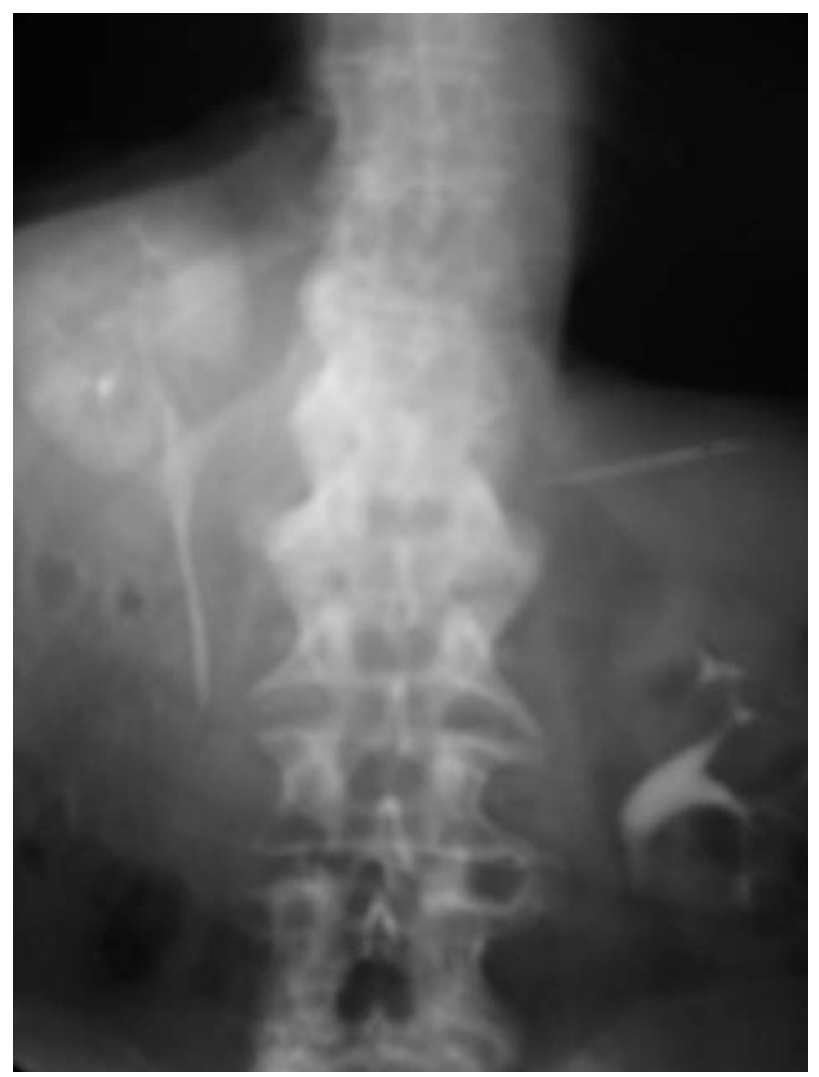

FIGURA 1 lización de urografía intravenosa, donde se observa una marcada elevación hemidiafragmática derecha con localización ectópica (subdiafragmática) del riñón ipsilateral, apreciándose lobulación del diafragma a ese nivel. Habiendo captación simétrica por parte de ambos riñones y no encontrando otros hallazgos de interés durante el resto de la prueba (Figs. 1 y 2).

Correspondencia autor: Dr. P. Garrido Abad

Servicio de Urología. Policlínica Nuestra Señora de América

E-mail autor: pgabad@hotmail.com

Información artículo: Imágenes en Urologia

Trabajo recibido: marzo 2006

Trabajo aceptado: abril 2006

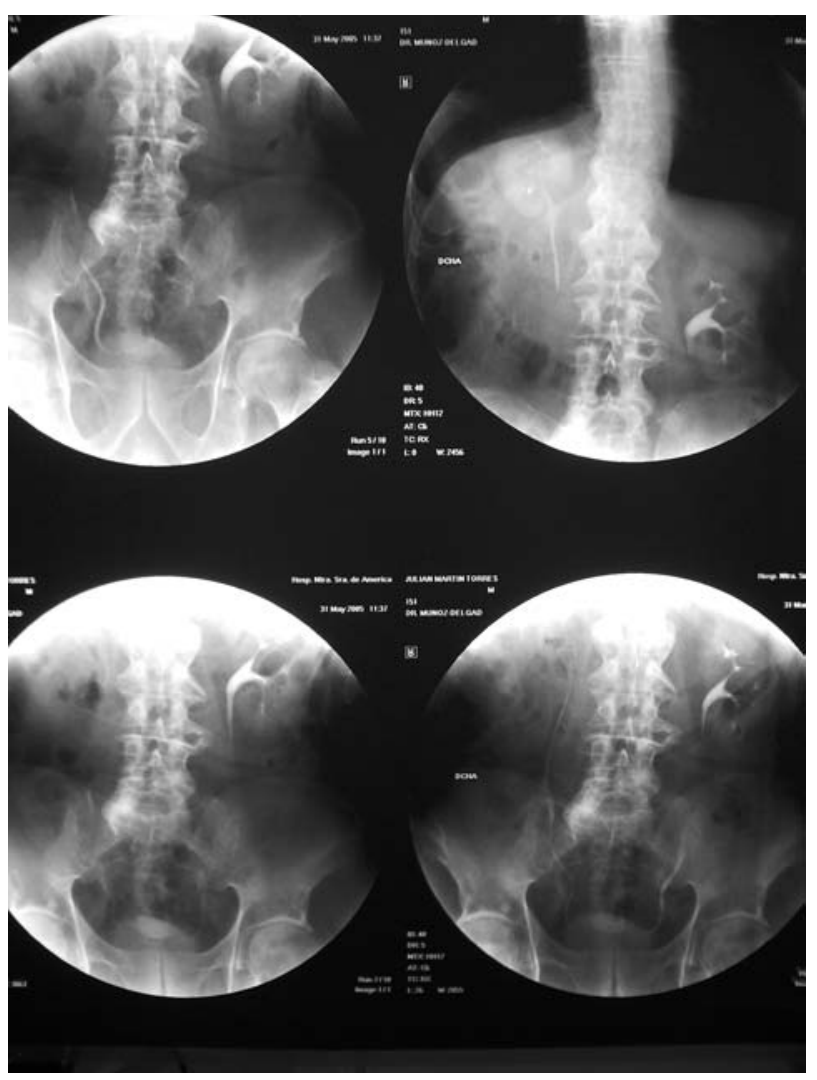

FIGURA 2 